\title{
EFFECT OF PLANT DENSITIES AND GENOTYPES ON FLAX AGRONOMIC TRAITS. 2- SEED YIELD, OIL YIELD, FIBER YIELD AND ITS COMPONENTS
}

\author{
E. H. El-Seidy*; T. A. Abou -Zied**, A. A. Hassan** and E.B. Assar ** \\ * Faculty of Agriculture, Tanta University, Tanta, Egypt \\ ** El-Gemmeiza Agriculture Research Station, Agriculture Research \\ Centre, Giza, Egypt. \\ *** Efficient Productivity Institute, Zagazig University, Zagazig, Egypt
}

\begin{abstract}
Two field experiments were conducted at two locations i.e. ElGemmeiza Agriculture Research Station, Gharbia governorate and Sakha Agricultnre Research Station, Kafr El- Sheikh governorate, Egypt during 2005- 2006 and 2006- 2007 seasons to study the effect of plant densities and genotypes on flax seed yield, oil yield, fiber yield and its components .

Results indicate that Egyptian flax varieties except Sakha 3 var. surpassed the imported varieties in straw yield, no. of seeds/ capsules, seed index, seed yield/ fad. and oil yield/ fad. in both seasons under the two experiments locations.

On the other hand the imported flax varieties and the Egyptian Sakha 3 variety exceeded all of the Egyptian varieties in fiber percentage and fiber yield/ fad. concerning the effect of plant densities on flax genotypes the obtained results indicate clearly that no. of capsules / plant, seed yield / fad. and Oil yield/ fad. were decreased by increasing plant density. While, increasing plant density had significant increases in straw yield/ fad, fiber percentage and fiber yield/ fad.
\end{abstract}

Keywords: Plant densities, genotypes, flax agronomic traits, seed yield, oil yield, fiber yield

\section{INTRODUCTION}

Flax (Linum usitatissimum. L.) is grown since long time in Egypt as a dual purpose field crop. Increasing Flax production is one of the important goals in Egypt, Since it is used widely as main source of fiber and oil for industry. 
Flax is grown in winter, it competes with wheat and clover, in addition to sugar beet which is widely grown especially in kafr El -Sheikh Governorate and thus the area is limited. At present it is rather difficult to increase the production of flax by increasing its area. From the stand point of view, raising flax yield from the limited area is very important. This could be achieved by improving the agronomic practices.one of the most important practices is the determination of the optimum seeding rate.

With respect to seeding rates, El-Shimy et.al (1993), El-sewifey (1993), Saad (1995), Abou-Zaid (1997), El-Deeb (2002), Omar (2002), and Mousa (2006), reported that the highest seeding rate caused an increment for each straw yield, fiber yield as well as seed yield/ fad, but Led to more thinner flax plants with lower number of capsules and lower straw and seed yield/ plant. Concerning the effect of genotypes on flax seed and fiber yields, Saad (1995) stated that there were significant effect between flax gemotypes for straw yield and its related characters on the same trend and the same tested strains varied significantly in seed yield and its related characters. El-sewifey and Mostafa (1996) pointed that S.2419 surpassed Giza 8 and Blenka varieties in seed yield and its related characters. On the other hand, Blenka variety gave the highest straw yield/fad. and also quality characters such as fiber length, fiber fineness and fiber percentage. Abou-Zaid and El-Gazzar (2001) reported that, Eriana variety gave the highest values in, plant height, technical. stem length, straw and fiber yields also fiber percentage and Giza 7 was the second order. On the other hand, Giza 8 ranked first in no. of capsules/plant, no. of seeds/capsule, stem diameter, seed index and seed yield per plant per faddan. Mousa (2002), noticed that, Sakha 1 variety gave the highest values in plant, technical. length, straw yield/plant or faddan, followed by Giza 7 variety, while Sakha 2 variety had the lowest for these characters, meanwhile, Sakha 2 variety scored the first order in seed yield and its related characters, followed by Giza 8 variety.

The present investigation was carried out to find the optimum seeding rate for incensing seed and fiber yields of some Egyptian varieties and some imported varieties of flax .

\section{MATERIALS AND METHODS}

The present investigation was carried out at El-Gemmeiza Agriculture Research Station, Garbia governorate and Sakha Agriculture Research Station, Kafr EL-Sheikh Governorate, Egypt, during the two 
successive winter seasons of 2005 / 06 and 2006 / 07, to study the effect plant densities on yield and yield components of some flax varieties.

\section{Factors of Study:}

\section{1- Varieties:}

1- Giza 4: Selected from across between Pink Giza $\times$ Oil Giza variety.

2- Giza 7: selected from across between Giza $5 \times$ New Rircr an introduction from USA and was released in 1990 by Fiber Crops Research Section.

3- Giza 8: Selected from across between Giza $6 \times$ Hira an introduction from India.

4- Sakha 1: Local commercial variety a dual purpose across between Bombay $\times$ S: (1)1485, and was released in 1999 by Fiber Crops Research Section.

5- Sakha 2: Local commercial variety a dual purpose across between I:2348 an introduction from Hungary $\times$ IH.Ka and was released in 1999 by Fiber Crops Research Section

6- Sakha 3: Selected from across between $1234 \times 12261$ as a fiber type and was released in 2006 by Fiber Crops Research Section.

7- Blenka: A fiber imported from Holland.

8- Escalina: A fiber type imported from Holland.

9- Marline: A fiber type imported from Holland.

10- Olina: A fiber type imported from Holland.

11- Hermes: A fiber type imported from Belgiun.

12- Errana: A fiber type imported from Switzerland.

\section{Plant Density:}

1- 1800 plants $/ \mathrm{m}^{2}$.

2- 2200 plants $/ \mathrm{m}^{2}$.

3- 2600 plants $/ \mathrm{m}^{2}$.

The sowing density (No. of seed $/ \mathrm{m}^{2}$ ) for studied varieties as shown in Table 1.The experimental lay out was a split plot design with four replications, at the two stations where varieties plotted in (A) main plots, and plant densities (B) were randomly distributed in sub plots. All agronomic Practices were done and $100 \mathrm{~kg}$ calcium super phosphate (15.5 $\mathrm{P}_{2} \mathrm{O}_{5}$ ) was applied to all plots as the recommended and $45 \mathrm{~kg} \mathrm{~N} / \mathrm{fad}$. was applied after the first and the second irrigations The normal cultural practices used in flax production were applied. 
EL-SIEDY ET AL 


\section{The Studied Characters:}

Ten plants were chosen randomly at harvesting time to estimate the following characters:

1- Number of capsules per plant.

2- Number of seeds per capsule.

3- Seed index (gm): It was determined as the average weight of 1000 seeds obtained from each plot.

4- Seed yield per faddan (kg) as estimated form one meter square of each plot.

5- Oil yield per faddan ( $\mathrm{Kg})$.

6- Straw Yield per faddan (ton): It was estimated from the sub plots and converted to record straw yield per faddan after removing the capsules.

7- Fiber Percentage: It calculated according to this evaluation:

$$
=\frac{\text { Weight of Fiber }}{\text { Weight of Total Straw after Retting }} \times 100 .
$$

\section{8- Fiber Yield per faddan (Kg).}

\section{Retting Process:}

The harvested straw of each sub plot plants was arranged in a boundle and put in retting basing at the fiber.

Section Gemmeiza after 50\% ling the straw for 24 hours and the water changed to each out the soluble materials.

Retting period lasted for about one week and the $\mathrm{pH}$ value of retting water was estimated by Backirian apparatus during this period, the average temperature of the water was 28-30 and the $\mathrm{pH}$ value was 6-7, while the ratio between straw and water was 1.13 when the $\mathrm{pH}$ of the retting water reached about $4.5 \mathrm{pH}$ and fibers were easily separated from straw the retted straw was washed with clean water and dried in open air, the retted dried straw was broken by special rolling machine. Then scotched and combed for extracting the flax fiber

\section{Statistical Analysis:}

The analysis of variance was used for this experiment according to Sndecor and Cochran (1981). The least significant difference (L. S. D) test at 0.5 . Level of significance was used to indicate treatment differences. 


\section{RESULTS AND DISCUSSIONS}

\section{1- Number of capsules/plant:}

Mean values of number of capsules/plant as affected by plant densities of the twelve flax genotypes in the two areas, experimental station and studied seasons are presented in Table 2.

Analysis of variance indicated significant differences among plant densities and genotypes in the two regions and 2005/2006, 2006/07 seasons.

Data indicated that , the number of capsules/plant affected by three plant densities. The highest number of capsules/plant were recorded under plant density at 1800 plants $/ \mathrm{m}^{2}$, followed by $2200 \mathrm{plants} / \mathrm{m}^{2}$. On the other hand, 2600 plants $/ \mathrm{m}^{2}$ gave the lowest number of capsules/plant at all treatments. These results could be attributed to the low competition among plants under low density which affected favorably the growth of plants, consequently resulted high number of capsules/plant. Similar results were reported by Sorour et al. (1992), Abou-Zaid and El-Gazzar (2001) and Omar (2002).

Regarding flax genotypes, The results cleared indicate that Sakha 2 variety was superior over the other genotypes in number of capsules/plant, followed by all the local varieties i.e., Giza 7 and Giza 8 varieties, while all imported varieties and Sakha 3 local variety gave the lowest number of this studied character. This significant differences may be due to the genetical differences and the degree of adaptation between different genotypes. These results are in harmony with those obtained by El-Sweify and Mostafa (1996), Omar (2002) And Mousa (2006).

\section{2- Number of seeds/capsule:}

Mean values of number of seeds/capsule as affected by plant density and flax genotypes in the two seasons 2005/06 and 2006/07 and under the two locations are presented in Table 2. Analysis of variance showed significant differences among plant density and genotypes in both seasons.

Results cleared that the highest number of seeds/capsules were recorded for plant density 1800 plants $/ \mathrm{m}^{2}$,followed by 2200 plants $/ \mathrm{m}^{2}$ while the density of 2600 plants $/ \mathrm{m}^{2}$ gave the lowest values in both farms and seasons. These results may be due to the competition between plants in light, water and nutrients as agreement with those of Lafond (1993), Esmail and Morsy (1994) and Saad (1995). 
Regarding flax genotypes, The results indicated that Sakha 2 variety gave the highest number of seeds/capsule , followed by Sakha 1 and Giza 8 in the first and the second seasons, while all imported varieties i.e. (Blanka, Herms and Sealina) gave the lowest number seeds/capsule. These results appeared the percentage of varieties differences due to genetical make up for each flax genotypes. These results agreed with those obtained by El-Shimy et.al (1993), Saad (1995) and Abou-Zaid (1997).

Results presented in Table (2) indicate that the highest number of seeds/capsule were obtained by Sakha 2 followed by Giza 8 and Sakha 1 in the first and the second seasons. Under the two studied locations.

\section{3- Seed index (gm).}

Mean values of seed index as affected by plant density and genotypes during the two seasons 2005/06 and 2006/07 are presented in Table (3). Statistical analysis indicated significant differences among densities in both seasons, increasing plant densities from 1800 to 2600 plants $/ \mathrm{m}^{2}$ decreased seed index, but it had no significant variances with plant densities in the two locations and in the two seasons. These results are in agreement with those of Sorour et al. (1992), Abou-Zaid and ElGazzar (2001) and Omar (2002).

Data in Table 3 revelated that there are significant differences in both regions and seasons, where Giza 8 surpused the other varieties followed by Sakha 1 and Sakha 2 as well as Giza 4 and Giza 7 , while the imported varieties i.e., Herms, Blenka, Olina, Marlina and Escalina gave the lowest values in seed index in the two areas and seasons. These results may be due to the genetical differences as reported by El-Sweify and Mostafa (1996), Omar (2002) And Mousa (2006).

\section{4- Seed yield (kg)/faddan:}

Mean values of seed yield/fad as affected by plant density and genotypes in the two locations and seasons are presented in Table 3. Analysis of variance results indicated significant differences among plant densities and genotypes. Data indicated significant differences and recorded the highest seed yield/fad by 1800 plants $/ \mathrm{m}^{2}$ followed by 2200 plants $/ \mathrm{m}^{2}$, while 2600 plants $/ \mathrm{m}^{2}$ gave the lowest values in both seasons. This high seed yield $\mathrm{kg} /$ faddan obtained from 1800 plants $/ \mathrm{m}^{2}$ may be attributed to the increase in number of aptical branches, number of capsules and number of seeds per capsule which in agreement with these of Awad et al. (1997), El-Borhamy (2003) And Kineber (2003). 
Regarding flax genotypes, the results showed that Giza 8 and Sakha 2 varieties gave the highest seed yield/fad, while Blenka and Herms varieties recorded the lowest values in this concern in the two successive seasons . Similar conclusion was reported by Omar (2002).

The obtained results indicate that Sakha 2 gave the highest seed yield followed by Giza 8, Giza 4 and Sakha 1 varieties, while Blenka and Harms varieties gave the lowest values in both seasons.(Table 3) These results are in agreement with those of El-Gazzar and Abou- Zaid (2001) And Mousa (2006).

\section{5- Oil yield ( $(\mathrm{gg}) /$ fad :}

Mean values of oil yield / (fad) as affected by plant densities, genotypes and the interactions between them at the two areas and 2005/06 and 2006/07 seasons are presented in Table 4. Results cleared significant differences for plant densities in oil yield/fad, in the two regions and seasons, increasing plant density decreasing oil yield/(fad). Sowing of 1800 plants $/ \mathrm{m}^{2}$ gave the highest oil yield/fad, followed by $2200 \mathrm{plants} / \mathrm{m}^{2}$ These results may be due to that the lowest density enhanced the branches of flax plants and increase the seed index as reported by Mohamed (1996), Abou-Zaid (1997) and El-Deeb (2002).

Results showed significant differences among the studied genotypes in their oil yield/fad. in both areas and seasons. However Giza 8 variety gave the highest oil yield/fad at all treatments, followed by all local varieties studies i.e., Sakha 2. Giza 4, Sakha 1, Giza 7 . on the other side, the imported genotypes i.e., Herms, Escalina, Ereana, Moklin and Oliva varieties gave the lowest oil yield/fad. These results perhaps due to the genetical differences as reported by Sorour et.al. (1992), El-Deeb (2002) and Omar (2002).

The effect of the interaction between flax varieties and plant densities on flax seeds oil was significant impact in both areas and seasons Table 4. However, the highest oil yield / fad were recorded by Giza 8 variety as treaded by second and third densities, followed by local varieties under the same density. While the lowest oil yield/fad was recorded by all the imported varieties under all densities in all regions and seasons as reported by Omar (2002) and Mousa (2002 and 2006).

\section{6-Straw yield (ton) faddan :}

Mean values of straw yield/faddan is affected by plant density, genotypes during 2005/06 and 2006/07 at Gemmeiza and Sakha farms are 
presented in Table 4. The results shows significant differences in straw yield/fad by using different plant densities in both seasons. Increasing plant density from 1800 plants $/ \mathrm{m}^{2}$ up to 2600 plants $/ \mathrm{m}^{2}$ increased straw yield/fad. This increasing may be due to number of plants/fad where sowing 2600 plants $/ \mathrm{m}^{2}$ gave the highest straw yield under all conditions. These results are in harmony with those of El-Deeb (2002), Abd-El-Daim (2004) And Mousa (2006)

The results revealed that the genotypes significantly differed in straw yield/fad at two farms and seasons where Blenka and Scalina varieties gave the highest straw yield/fad under all treatments. On the other hand, Sakha 3 and China varieties gave the lowest values in all farms and seasons under this study. All difference from results may be due to difference on genetically constitution of the tested genotypes under this study. These results are in agreement with those obtained by El-Shimy et al. (1993), Abou-El-Dahab (2002) and Abou-Zaid and El-Azony (2003)

The results indicate that plant densities and genotypes had a significant impact in all conditions and two seasons, where results cleared that Sakha 1, Sakha 2 and Giza 8 under 1800 plants $/ \mathrm{m}^{2}$ gave the highest values in straw yield/fad. These results may be due to the higher adaptation for local varieties Abd-El-Daim (2004) had no harmony with these results in this study.

\section{7- Fiber percentage:}

Mean values of fiber percentage as affected by plant density and genotypes during the two seasons 2005/06 and 2006/07 at the Sakha and El-Gemmeiza Research Stations are shown in Table (5 ) results cleared significant effect of plant densities and genotypes on fiber percentage in both seasons.

The highest values of fiber percentage were obtained by plant density of 2600 plants $/ \mathrm{m}^{2}$, followed by 2200 plants $/ \mathrm{m}^{2}$, while the density of 1800 plants $/ \mathrm{m}^{2}$ gave the lowest values in both seasons and regions. These results may be due to the competition between plants on lights and nutrients as reported by El-Deeb (2002), Omar (2002) and Mousa (2006).

Also, data in Table 5 show significant differences among genotypes in both areas and seasons where the imported varieties out yielded than local ones for fiber percentage in both successive seasons however Sakha 3 variety an equal footing with the imported varieties at all conditions.

These results may be due to the genatical difference as reported by. El-Deeb (2002), Omar (2002) and Mousa (2006). 
The highest fiber percentage was obtained by imported varieties included Sakha 3 variety under 2600 plants $/ \mathrm{m}^{2}$, while local varieties ,except Sakha 3 variety under 1800 plants $/ \mathrm{m}^{2}$ gave the lowest fiber percentage in the two seasons and areas.

\section{8 - Fiber yield/fad (kg):}

Mean values of fiber yield $(\mathrm{kg}) /$ fad as affected by plant densities and genotypes at Sakha and El-Gemmeiza regions in 2005/06 and 2006/07 seasons are presented in Table 5.

Results showed significant differences due to plant density for fiber yield/fad in two regions and seasons. Increased plant density from 1800 plants $/ \mathrm{m}^{2}$ up to 2600 plants $/ \mathrm{m}^{2}$, increasing fibers yield/fad where 2600 plants $/ \mathrm{m}^{2}$ gave the highest fiber yield followed by 2200 plants $/ \mathrm{m}^{2}$. On the other hand, 1800 plants $/ \mathrm{m}^{2}$ gave the lowest values. This increasing may be due to the increase in number of plants as well as plant height and technical stem length as reported by El-Shimy (1993), Easson (2000) and Omar (2002).

Analysis of variances showed significant among flax genotypes where all imported flax genotypes and also, Sakha 3 variety gave the highest values in fiber yield $(\mathrm{kg} / \mathrm{fad})$, while all local varieties, gave the least values of fiber yield $(\mathrm{kg} / \mathrm{fad})$. These results may be due to the genetical differences. These results, are in harmony with those reported by Mohamed (1996), Abou-Zaid (1997) and El-Deeb (2002).

Conclusively, from these results it could be concluded that all imported varieties under any plant density gave the highest fiber yield/fad $(\mathrm{kg})$. On the other hand, the local varieties under 1800 plants $/ \mathrm{m}^{2}$ gave the lowest values for the trait in question, except Sakha 3.

\section{REFERENCES}

Abd El-Daim (2004). Evaluation of some flax genotypes under different plant densities .Msc .Thesis Fac of Agric El-Azhar University, Egypt.

Abou-Zaid.T. A. (1997). Comparative study of yield and technological characters of some flax varieties. Ph. D. Thesis, Faculty of Agriculture, El-Mansoura University, Egypt.

Abou-Zaid, T. A. and A. El-Gazzar (2001). Effect of seeding rate and nitrogen levels on yield and quality of some flax cultivars. Journal of Agriculture Research, Tanta University, Egypt, 27 (7): 620-632. 
Abou-Zaid, T. A. and A. M. Al-Azony, (2003). Response of flax to soil leveling, planting methods and seeding rates. Journal of Agriculture Science, Mansoura University, 28 (9): 6577-6589.

Abu El-Dahab, A. A. (2002). Effect of seeding rate on yield of some flax cultivars. Journal of Agriculture Science, Mansoura University, 27 (4): 2005-2017.

Awad, A. M.; A. M. Abd El-Wahab; H. M. Abd-Mottaleb and M. M. Hussein (1997). Effect of seeding rate and nitrogenous fertilizer level on flax. Journal of Agriculture Science, Mansoura University, 22 (11): 3553-3560.

Easson, D. L. (2000). Method of retting flax and linseed and their effects on fiber yield and quality. Aspects of Applied Biology, 65: 117-122.

El-Borhamy, A. M. (2003). Effect of sowing density and retting methods yield and quality of same flax cultivars M. Sc. Thesis, Faculty of Agriculture, Kafer El-Sheikh, Tanta University Univ., Egypt.

El-Deeb, E. A. (2002). Comparative studies of some quantitative and qualitative traits of some flax genotypes. PhD. Thesis, Faculty of Agriculture, Moshtohor, Zagazig University, Egypt.

El-Shimy, G. H., E. A. F. El-Kady and N. K. M. Mourad (1993). Effect of seeding rates and nitrogen fertilizer levels on yield and anatomical manifestation of some flax genotypes. Journal Agriculture Research, Tanta University, 19 (1): 92-104.

El-Sweify, H. H. (1993). Evaluation of some promising flax strains in relation to growth, yield and quality. Ph. D. Thesis, Faculty of Agriculture, Moshtohor, Zagazig University, Egypt.

El-Sweify; H.H .and S. H. A. Mostafa. (1996). Growth, yield and quality of flax as affected by genotypes, potassium fertilizer and plant densities. Egyptian Journal of Science, 11 (7): 116-133.

Esmail, S. E. and M. R. Morsy. (1994). Flax plants performances influenced by seeding rate and harvesting date and their response curves. Menofiya Journal Agriculture Research, 19 (5): 2243-2255.

Kineber, M. E. A. (2003). Flax plant performance as influenced by planting methods and seeding rate. Journal Agriculture Research, Tanta University, 29 (1): 64-73..

Lafond, G. P. (1993). The effects of $\mathrm{N}$, row spacing and seeding rate on the yield of flax under a zero-tillage production system. Canad. $H$. of Plant Science, 73 (2): 375-382. 
Mohamed, A. A. E. (1996). Influence of seeding rate and nitrogen level on yield and some technological characters of flax. Proceeding $7^{\text {th }}$ Conference of Agronomy, 9-10 Sep., 379-389.

Mousa, A. M. A. (2002). Effect of weed control on yield and quality for some flax varieties. M. Sc., Thesis, Faculty of Agriculture, Al-Azhar University, Egypt.

Mousa.A.M.A. (2006). Response of some flax varieties for soil and foliar application nutrients. Ph. D. Thesis, Faculty of Agriculture, El-Azher University, Egypt.

Omar, T. S. (2002). Response of some flax strains to row spacing and nitrogen fertilization. Ph. D. Thesis, Faculty of Agriculture, Moshtohor, Banha University, Egypt.

Saad, A. M. M. (1995). The performance of flax varietal characters contributing to straw and/or seed yield production. Annual Agriculture Science, Moshtohor, Banha University, Egypt, 33 (1): 101-108.

Sndecor, G. W. and W. G. Cochran. (1981). Statistical Method. $7^{\text {th }}$ edition, Lawa State Univ., Press Ames, Lawa USA, 325-330.

Sorour, S. G.H; S. H. Abou-Khadrah; S. A. Youssef; E. A. El-kady and A. A. El-Gazzar (1992). Effect of planting pattern and seeding rate on growth, yield and quality of some flax varieties. Proceeding $5^{\text {th }}$ Conference of Agronomy, Zagazig, 2: 836-850. 


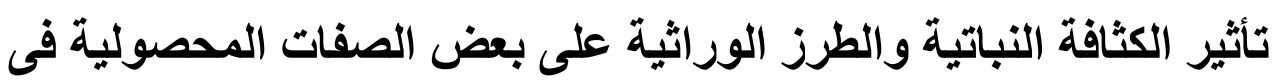

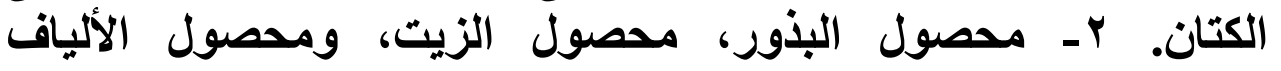
ومكوناتهما

السيد حامد الصعيدى*، طه عبد المنعم أبو زيد*** ، على عبد الحميد حسان*** ، * * * الموافى بلير عصر.

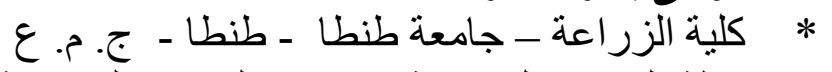

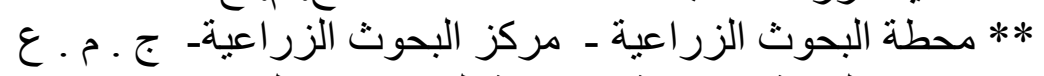

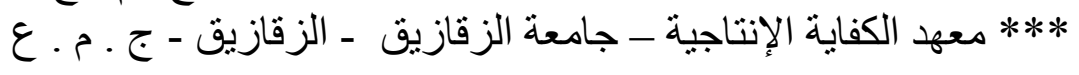

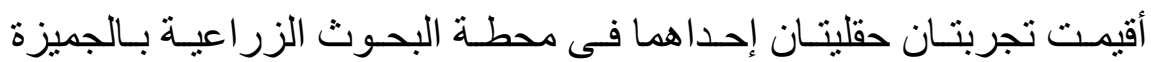

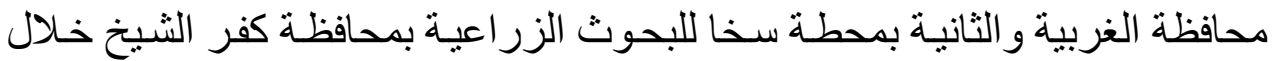

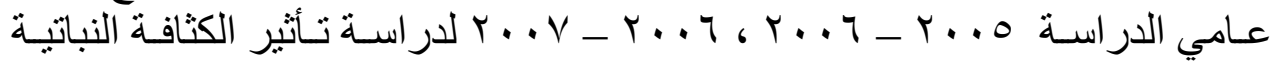

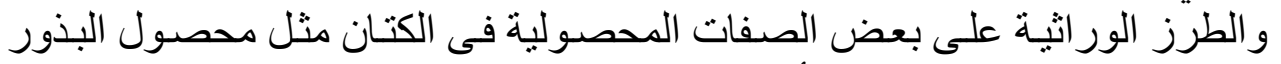
ومحصول الزيت ومحصول الألياف ومكوناتهما.

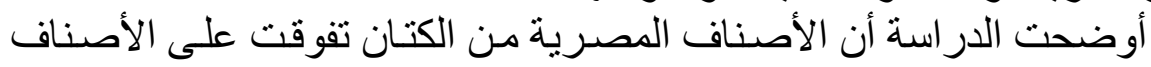

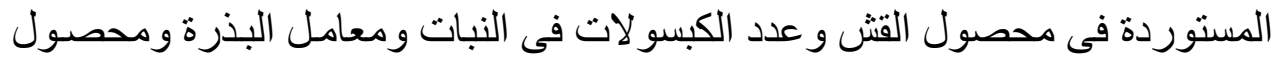

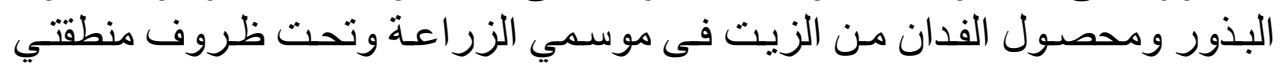

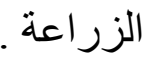

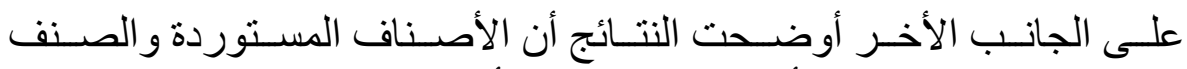

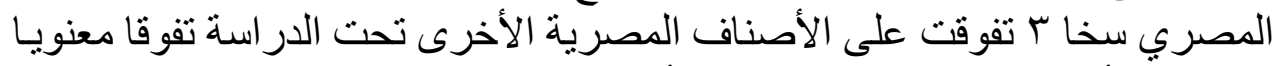
فى نسبة الألياف ومحصول الفدان من الألئ الألياف

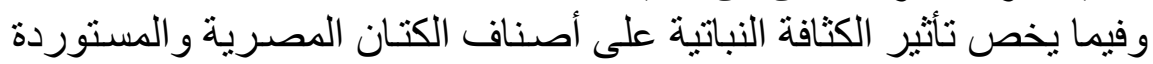

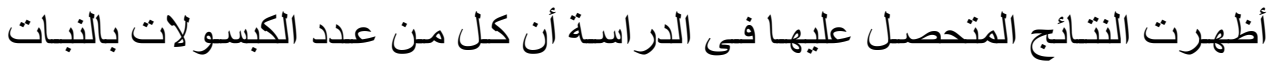

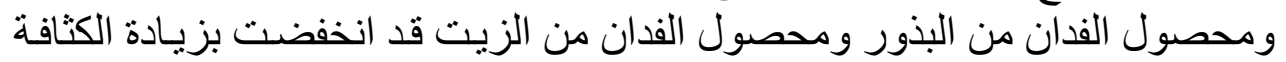

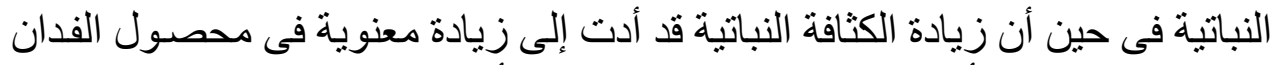

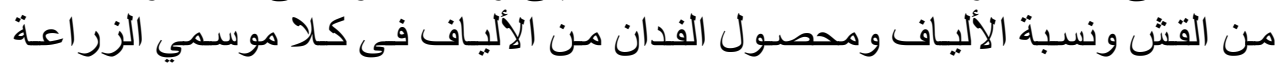

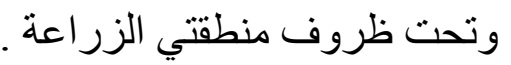

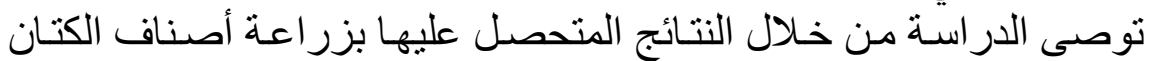

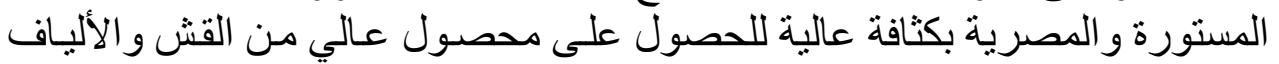

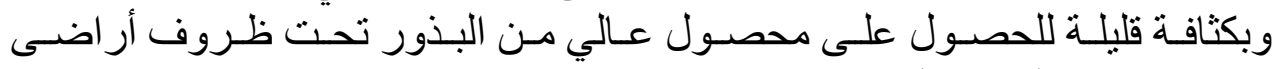

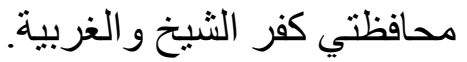

